\title{
Dijital Pazarlama ve Markaların Müşteri Memnuniyeti
}

\author{
Digital Marketing and Brands' Customer Satisfaction of Brands
}

\section{Kürşad ÖZKAYNAR}

Dr. Ögrr. Gör., Sivas Cumhuriyet Üniversitesi,

Zara Ahmet Çuhadaroğlu MYO, kursadozkaynar@gmail.com

https://orcid.org/0000-0003-1683-9591

\section{Tark YOLCU}

Dr. Öğr. Üyesi, Sakarya Uygulamalı Bilimler Üniversitesi,

Hendek Meslek Yüksekokulu, tyolcu@subu.edu.tr

https://orcid.org/0000-0002-4483-7860
Makale Başvuru Tarihi: 18.11.2021

Makale Kabul Tarihi: 27.12.2021

Makale Türü: Araştırma Makalesi

\begin{abstract}
Anahtar
Kelimeler:

Dijital Pazarlama,

ÖZET

Marka,

Tüketici

Davranışları,

Sosyal Medya,

e-Ticaret,

Teknolojinin ilerlemesi ile beraber dijitalleșen hayat, tüketicilerin internet ortamında daha fazla vakit geçirmesine neden olmuştur. Bu durum, işletmelerin de dijital evrende yer almasını zorunlu kllmış; markalar, web siteleri, sosyal medya hesaplarl, elektronik pazaryerleri vb. ortamlarda varlık göstermeye başlamışlardır. Alışverişin değişen kuralları sonucunda pazarlamanın uygulama sahası genişlemiş ve markalar, müşterilerine daha fazla ulaşma imkânı bulmuşlardır. Aynı zamanda müşsteriler de markalara birçok farklı kanaldan ulaşma, istek ve şikayetlerini iletme şansı yakalamışlardır. Karşılıklı artan bu etkileşim, beraberinde, müşteri memnuniyetinin sağlanmasinda avantajlar ve dezavantajlar getirmiştir. Çalıșmada, dijital mecraların önemine, doğru kullanım şekillerine ve müșteri memnuniyetinin sağlanması için dikkat edilmesi gereken hususlara değinilmiştir. Sonuç olarak internetin ortaya çıkmasından bugüne kadar uzun süre geçmesine rağmen, özellikle sosyal medya mecralarının yanlış kullanımına vurgu yapılmış, bunun önüne geçilmesi için önerilerde bulunulmuştur.
\end{abstract}

\section{Keywords:}

Digital Marketing,

Brand,

Consumer

Behavior,

Social Media,

e-Commerce,

\begin{abstract}
With the advancement of technology, digitalized life has caused consumers to spend more time online. This situation has made it necessary for businesses to take part in the digital universe; brands, websites, social media accounts, electronic marketplaces, etc. have begun to exist in environments. As a result of the changing rules of shopping, the application field of marketing has expanded and brands have found the opportunity to reach their customers more. At the same time, customers have had the chance to reach brands through many different channels and convey their requests and complaints. This mutually increasing interaction has brought advantages and disadvantages in ensuring customer satisfaction. In the study, the importance of digital channels, their correct use, and the issues that need to be considered to ensure customer satisfaction are mentioned. As a result, although it has been a long time since the emergence of the internet, especially the misuse of social media channels has been emphasized and suggestions have been made to prevent this.
\end{abstract}




\section{GIRISS}

Pazarlama disiplininin teknolojiden ayrı olarak geliştiğini veya değiştiğini söylemek güçtür. Her dönemin kendine ait teknolojik özellikleri, ister gelişme, ister değişme, isterse devrim niteliğinde olsun, mutlaka pazarlama disiplinine etki etmiştir. Bu etki, internet ve sosyal medya örneğinde olduğu gibi çoğu kez tutundurma karmasında daha fazla ön plana çıkmaktadır.

Özellikle tarih boyunca devrim niteliğindeki, matbaanın bulunması, ses ve görüntünün iletilmesinde sağlanan gelişmeler ile radyo ve televizyonun hayatımıza girmesi ve son olarak internetin ortaya çıkışı, pazarlama disiplininin gelişimi ile eşzamanlı seyir izlemektedir. Ryan da (2014:5) teknolojik gelişmeler ile pazarlama disiplininin evriminin adeta birbirlerine kenetlendiğini ifade eder. Buna göre, teknoloji ile pazarlama tarihinin belli başlı kilometre taşları aşağı yukarı şu şekilde işler;

1. Yeni teknoloji ortaya çıkar ve teknoloji uzmanlarıyla ilk geliştiricilerin muhafazasındadır.

2. Teknoloji pazarda daha sağlam bir yer edinir ve popülerleşir, böylece pazarlama disiplinin ve uygulayıc1ların radarına girer.

3. İnovatif pazarlamacılar hedef kitlelerine ulaşmak için bu yeni gücü ehlileştirebilmenin yollarını ararlar.

4. Teknoloji anaakıma göçer ve standart pazarlama etkinliğinin parçası haline gelir.

Bugün de bu adımlar hemen hemen gerçekleşmiş, internet ve bağlı teknolojilerin gelişmesi, öncül inovatif teknolojiler ve ardıl ürünler ile pazarlamanın dijitalleşme süreci başlamıştır. Bu sürecin kendine has teknolojileri olduğu gibi, nevi şahsına münhasır hayat tarzı ve kuralları da vardır. Tüm bunlar bir araya geldiğinde artık yeni ekosisteme dijital çağ adını vermek kolay olacaktır. Dijital çağa uygun olarak pazarlama da yoğun şekilde dijitalleşmiş, markalar, müşterilerine ulaşmak için dijital dünyanın araçlarını ve argümanlarını yoğun olarak kullanmaya başlamışlardır. Arthur'un (2011:231) ifade ettiği gibi,

"bu şekilde modern teknolojinin doğasl, şirket yönetiminden üretim süreçlerinin optimum hale getirilmesine ve yeni kombinasyonların (yeni ürünlerin, yeni işlevselliklerin) yaratılmasına kadar bir çok alanda bir dizi yeni değişim gündeme getirmektedir: rasyonellikten anlam vermeye; ürün temelli şirketlerden beceri temelli şirketlere; bileşenler satın almaktan ittifaklar kurmaya; sabit hal faaliyetlerinden kesintisiz uyarlanmaya geçişi gündeme getirmektedir. Bu geçişlerin hiçbiri birden bire olmaz. Aslında eski ve yeni tarzların unsurları ekonomide bir arada olur".

Çalışmanın ilerleyen kısmında dijital çağın yenilikleri doğrultusunda yapılan çalışmalarda yer yer geleneksel pazarlamanın tekniklerinin ve yöntemlerinin nasıl kullanıldığı örneklendirilmiştir. Bu çalışmada eski ve yeni olarak basit şekilde ifade edilen süreçleri Schmidt ve Cohen (2014:281) daha iddialı bir söylemle dile getirirler. Onlara göre tüm mesele iki uygarlığın hikayesidir. Bu uygarlıklardan ilki, insanoğlunun binlerce yıldır inşa ettiği ve gelişme halindeki fiziksel uygarlık, diğeri ise henüz oluşum aşamasındaki sanal, daha doğru bir ifadeyle dijital uygarlıktır. Yeni inşa edilen, oluşma ve olgunlaşma seyrindeki uygarlıkta pazarlama ve dijital pazarlamanın yeri ne olacaktır, aşağıdaki bölümde bu konu ele alınmıştır.

\section{DİJITTAL PAZARLAMANIN GEREKLİLIĞİ}

Yolcu ve Arslan'ın (2020) Tarabasız'dan (2013) uyarladığı tablo, pazarlama anlayışının teknoloji ile olan etkileşimini ifade etmesi açısından önemlidir.

\begin{tabular}{|c|c|c|c|c|}
\hline & Pazarlama 1.0 & Pazarlama 2.0 & Pazarlama 3.0 & Pazarlama 4.0 \\
\hline Amaç & Ürün satı̧ıı & Müşteri tatmini & $\begin{array}{c}\text { Daha yaşanabilir bir } \\
\text { dünya }\end{array}$ & $\begin{array}{c}\text { Bugünden geleceği } \\
\text { yaratmak }\end{array}$ \\
\hline $\begin{array}{c}\text { Ortaya çıkma } \\
\text { nedeni }\end{array}$ & Sanayi devrimi & Bilgi teknolojileri & Yeni dalga teknolojiler & $\begin{array}{c}\text { Sibernetik devrim ve Web } \\
4.0\end{array}$ \\
\hline $\begin{array}{c}\text { Ana pazarlama } \\
\text { kavramı }\end{array}$ & Ürün geliştirme & Farklılaştırma & Değerler & Kitlesel özelleştirme \\
\hline Değer önermesi & Fonksiyonel & Fonkiyonel ve duygusal & $\begin{array}{c}\text { Fonksiyonel, duygusal } \\
\text { ve ruhsal }\end{array}$ & $\begin{array}{c}\text { Fonksiyonel, duygusal, } \\
\text { ruhsal ve bireysel yaratıcllık }\end{array}$ \\
\hline Müşteriyle ilişkiler & Birden çok'a operasyon & Birebir ilişki & Çoktan çok'a işbirliği & $\begin{array}{c}\text { Çoktan çok'a işbirliği ve } \\
\text { birlikte yaratma }\end{array}$ \\
\hline
\end{tabular}


Hal böyle iken günümüz dünyasında dijital pazarlamanın gerekliliği şeklinde bir başlık çok anlamsız görünebilir. Ancak sahaya baktığımızda orta büyüklükte ve küçük işletmelerin bir çoğunda dijital mecra kullanımının, bilinçli bir karardan ziyade, başkalarında olan bizde de olsun mantığında gerçekleştiğini görmek mümkündür. Güncellenmeyen internet siteleri, doğru dürüst paylaşım yapılmayan sosyal medya hesapları, bakılmayan ve cevaplanmayan elektronik postalar söz konusu iddiamızı doğrular niteliktedir. Oysa dijital dünya işletmeler için sayısız firsatlar barındırmaktadır. Sadece geleneksel pazarlama ile dijital pazarlama arasındaki reklam bütçeleri farkı bile fırsatların büyüklüğünü göstermesi açısından önemlidir.

İşletmelerin büyük bir kısmı, işlerinin ya da ürünlerinin dijital mecralar için uygun olmadığını gerekçe göstererek bu konuda ihmalkar davranmaktadırlar. Oysa, göz ardı ettikleri en önemli gerçek, ürünleri veya işlerinden ziyade müşterilerinin dijital dünyada yerlerini aldığı gerçeğidir.

Dijital pazarlamanın gerekliliğini vurgulamak için dünyada ne kadar insanın dijital olduğuna bakmak muhtemelen yeterli bir gösterge olacaktır. Hootsuite (2021) tarafından her yıl düzenli olarak yayınlanan "We are Social" raporunun 2021 Ocak nüshasına göre mobil telefon kullanıcıları, dünya nüfusunun \% 66,6'sına ulaşmıştır. İnternet kullanıcılarının oranı dünya nüfusunun \% 59,5'lik kısmına ulaşmışken, aktif sosyal medya kullanıcıları dünya nüfusunun \% 53,6'sına ulaşmışlardır. Bu oranlara, çok yaşlı nüfus, bebek ve çocuk nüfusu ile teknolojik alt yapı olarak yetersiz bölgeler de dahil edildiğinde dünya nüfusunun ne kadar büük bir kısmının dijitalleştiği anlaşılacaktır. Söz konusu rapora ait grafik aşağıdaki gibidir;

Grafik 1. Dünya Dijital Haritası

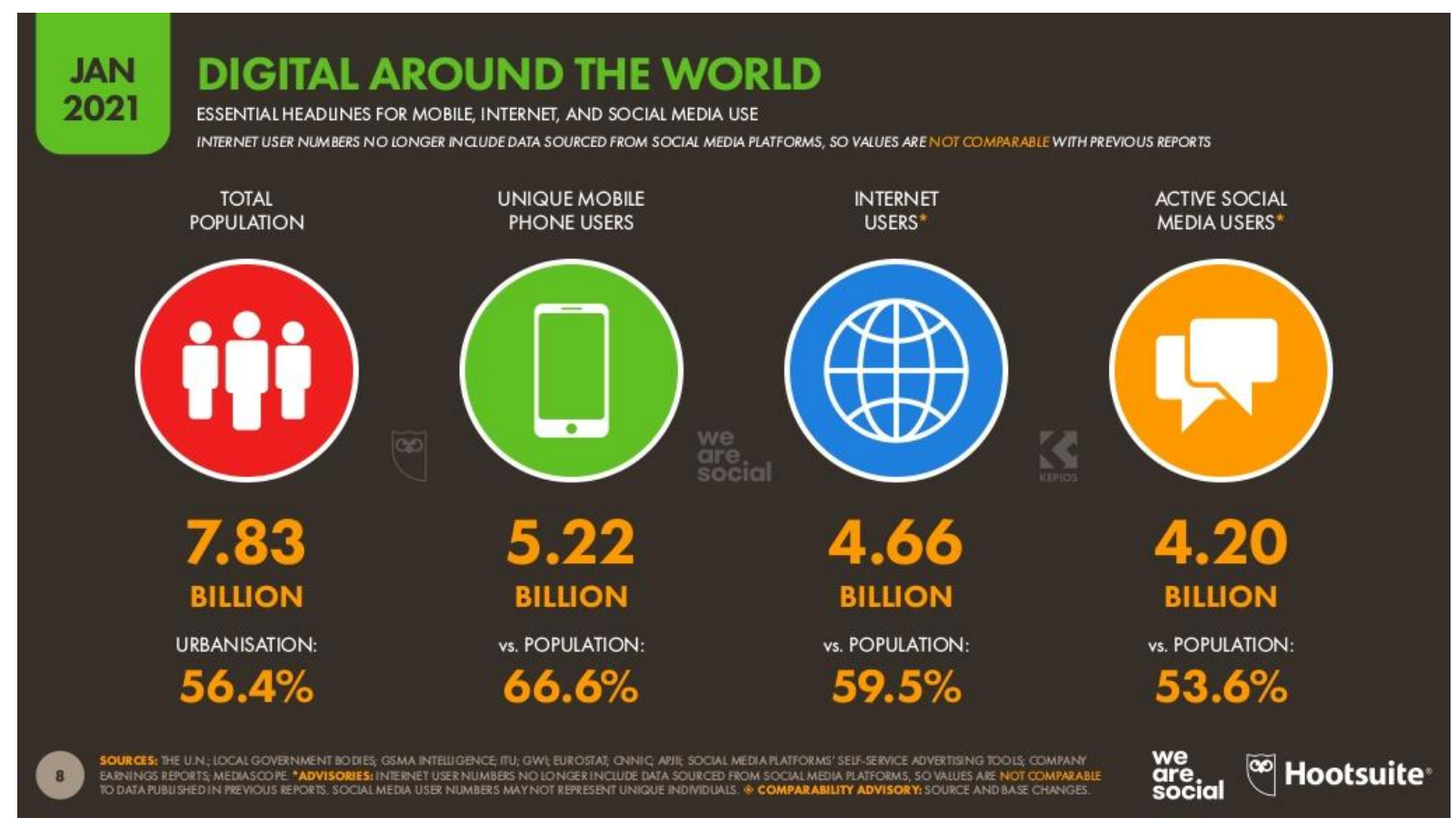

Kaynak: We are Social, Hootsuite, 2021

Yukarıdaki grafikte de görüldüğü üzere, dünya üzerinde neredeyse hemen herkesin internet sitesi veya sosyal medyası olduğu durumundan hareketle, işletmenin dijital dünyada yer almasını arzu edenlerin genelde izlediği yol, alan yazında da belirtilen adımların basit halidir. Bu adımları Chaffey ve Smith'den (2013) aktaran Koçak Alan vd. (2018:495), elde et, kazan, ölç ve optimize et, sahip çık ve büyüt olarak ifade etmektedirler. Oysa Rayn (2014:33) sağlam bir dijital temel atmanın önemine daha çok vurgu yapar. Dijital pazarlama stratejisinin temelini oluşturan bileşenleri;

- İşini tanı

- Rekabeti tan1,

- Müşterilerini tanı,

- Ne yapmak istediğini bil,

- Nasıl yaptığını bil şeklinde ifade etmektedir. 
Burada akla şöyle bir soru gelebilir. İnternette olan insanların bu aktivitelerinin ne kadarı alışveriş ile ilgilidir. Yine söz konusu rapora göre (Hootsuite, 2021) kullanıcıların öncelikli kullanım amacı olarak yaptıkları sıralamada ürün ve marka araştırmaları için interneti kullanım oranı \%46,4 olarak ifade edilmektedir. Bu orana, diğer insanların da ikincil veya ardıl internet kullanım sebepleri arasında alışverişin olduğu/olabileceği eklenince internette ne kadar büyük bir müşteri kitlesinin olduğu rahat anlaşılabilir. İnternet kullanım amacına yönelik grafik aşağıdaki gibidir;

Grafik 2. İnternet Kullanım Gerekçeleri

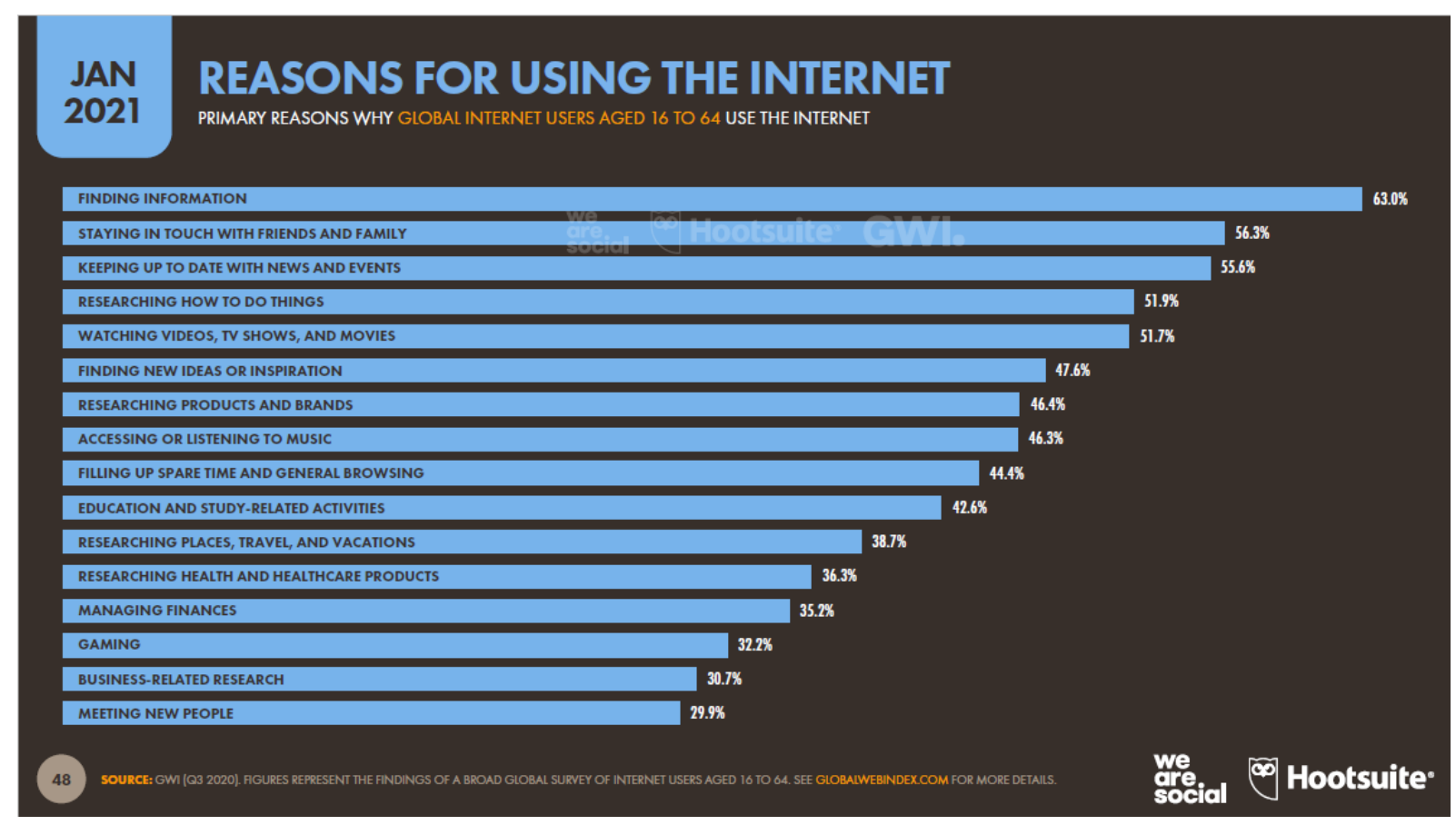

Kaynak: We are Social, Hootsuite, 2021.

\section{DİJITTAL PAZARLAMADA ATILMASI GEREKEN DOĞRU ADIMLAR}

Herşeyin olduğu gibi ürünlerin de markaların da dijital platformlara taşındığı konusu hemen herkesin üzerinde ittifak ettiği bir durumdur. Demir ve Yıldız'ın da (2021) belirttiği gibi, müşterilerin ihtiyaçlarını ve isteklerini anlamak için bu dijital platformlardaki etkileşimlerine dikkat etmek gerekir. Ancak en küçüğünden tutun en büyük işletmelere kadar dijital mecraya taşınan ya da hali hazırda taşınmak isteyenlerin dikkat etmeleri gereken adımlar mevcuttur. Bu adımları kısaca başlıklar halinde açıklayabiliriz.

\subsection{Dijital Dünya - Gerçek İnsan}

Dijital dünyada yer alan veya taşınmak isteyen kurumların dikkat etmesi gereken ilk konu buradaki müşteri kitlesinin gerçek insanlardan ibaret olmasıdır. İnternetin ilk çıktığı dönemlerde dijital dünyanın, sanal alem olarak adlandırılması, internetin sohbet odalarından ibaret sanılması ve bu odalarda insanların sahte adlarla (nick name) yer alması, internetin tamamen sanal olarak algılanmasına yol açmıştır.

Gerçekten bugün de sosyal medya hesaplarında gerçek olmayan isim ve kimliklerin kullanımı elbette devam etmektedir. Ancak bu durumun giderek azaldığ 1 görülmektedir. İnternet kullancıları giderek dijital dünyanın olası tehlikelerini kavramış, kendilerini korumaya yönelik tedbirleri almaya başlamışlardır. $\mathrm{Bu}$ durum neticesinde de gerçek kimlikleri ile sosyal medya hesaplarında kullanıcılar aktifleşmişlerdir. İnsanların gerçek ad ve soyad bilgileri ile dijital dünyada yer almasının bir diğer sebebi de firmalar ile iletişime geçme yani alışveriş yapma arzusudur. Yapılan alışveriş neticesinde sipariş, ödeme, kargo ve alışveriş sonrası hizmetler için tabi ki resmi bilgiler gerekmektedir.

İşletmeler ellerindeki bu devasa boyuttaki veri tabanını (ki buna big data diyoruz) her ne kadar toplu analiz etse de her bir datanın ayrı bir insan olduğu gerçeğini göz önünde bulundurmalıdırlar. Firmaların önündeki tek dikkat çekici konu bu değil elbette. Bu konunun devamında daha önemli bir durum mevcut. Buna kısaca dijital kabileler denilebilir. 
Markanın ulaştığı insanın, kendi arzusuna göre markayı övmesi veya yermesi, ürünleri yahut hizmetleri kendine saklaması ya da paylaşması konusu da işletmeler için hayati derecede önemlidir. Başarılı bir çalışmanın viral etki yaratma ihtimali, hem maddi hem manevi anlamda işletmeler için dijital dünyanın bulunmaz nimetleri arasında sayılabilir. Mutlaka bu durumun tersi de söz konusu olabilir. Yani, firma hakkındaki olumsuz bir görüntünün, videonun veya yargının da viral olma ihtimali gerçeği unutulmamalıdır. Bu konuya müşteri memnuniyeti kısmında değinilecektir.

Müşteri memnuniyeti konusundan önce dijital müşteriyi tanımak, anlamak gerekmektedir. Çünkü dijital müşteri bazı alanlarda normal müşteriden farklı özellikler gösterebilir. Aksoy'a göre (2020) tüketiciler öncelikle hızı seviyor, hızı arıyorlar. Hızlı yüklenmeyen web sayfalarından, telefonları ile uyumsuz sitelerden kaçış başlıyor, bu sayfalar anında eleniyorlar. Ayrıca dijital müşterilerin bilgi alma konusunda da yoğun talepleri mevcut. Bilgi almak isteyenlere hızla dönüş yapılmazsa, bu işletmeler müş̧terilerin odağından çıkıyorlar. Bir diğer konu güven konusudur. Müssterinin mağazada gördüğü ile internette gördüğü ürün ve fiyatların aynı olması da büyük önem taşımaktadır. Herhangi bir farklılık söz konusu olursa firmaya güven anında düşüyor. Bu güveni inşa edecek diğer bir konu da şeffaflıktır. Firmaların şeffaf davranmaları, dijital tüketicilerin beklentileri arasında yer almaktadir.

Dijital müşterilerin en önemli özellikleri işletmelere verdikleri bilgilerin özensizce kullanılıp kullanılmamasıdır. Tahmin edileceği üzere bu müşteri tipi, kendisini sürekli rahatsız eden firmalardan hoşlanmamaktadır. Buna önlem olarak da reklamları engelleyen / bloklayan yazılımlar veya programlar kullanmaktadırlar. Hootsuite (2021) raporuna göre bu konudaki dünya ortalaması \% 42,7 olarak gerçekleşmiştir. Türkiye ortalaması da dünya ortalamasına çok yakındır. İlgili grafik aşağıdaki gibidir;

Grafik 3. Ad Blockers Kullanım Oranları

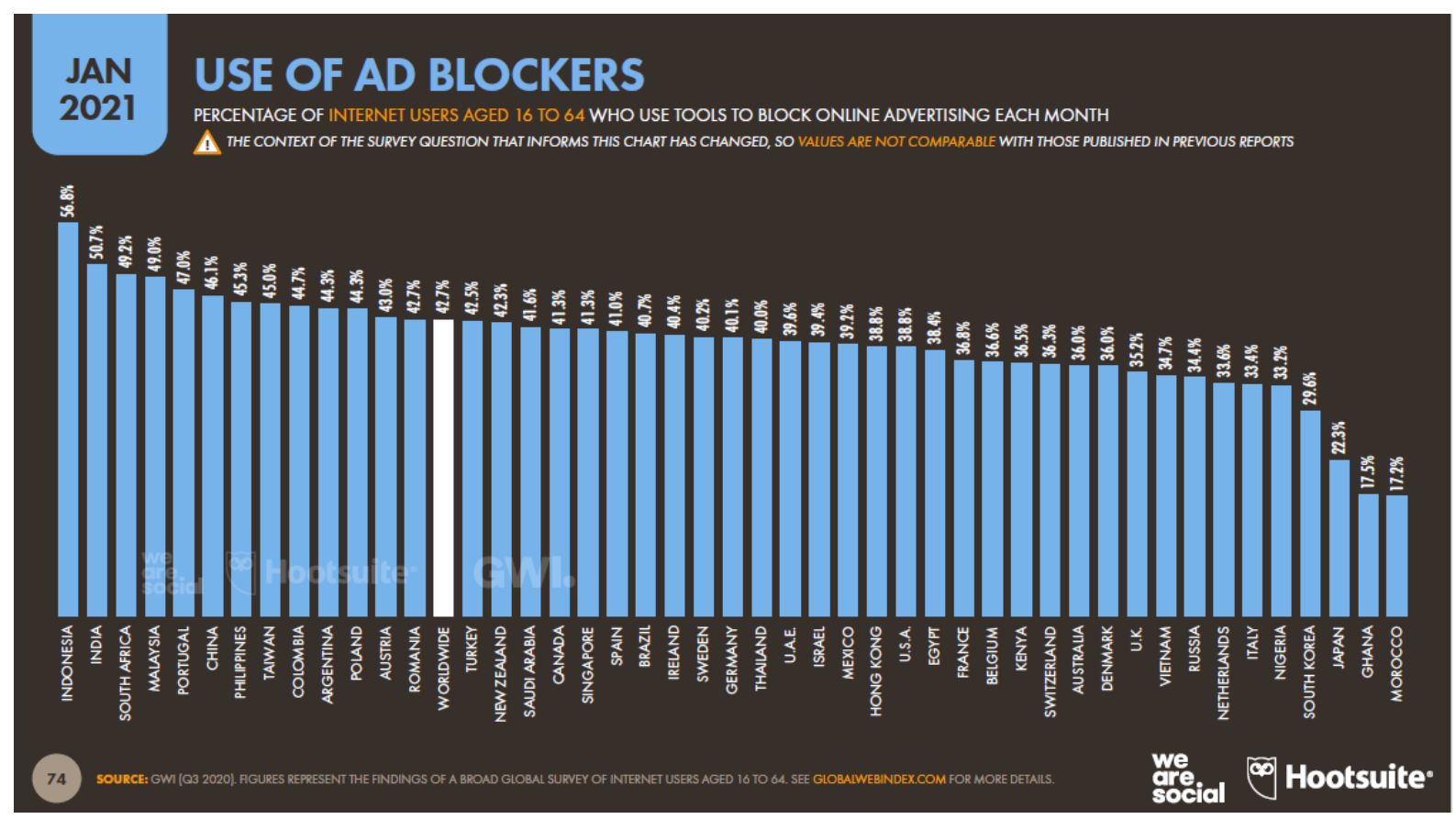

Kaynak: We are Social, Hootsuite, 2021.

\section{DİJITAL PLATFORMLARDA MARKANIN KURGULANMASI}

Dijital platformlarda markaların yeniden inşası ifadesi tartışmaya açık gibi görünebilir. Ancak, marka ne kadar köklü olursa olsun, yeni dünyaya uyum sağlamak zorundadır. Zira teknoloji kullanımının yaygınlaşmasının tüketici davranışı üzerinde farklı etkileri vardır (Ryan, 2014:19). Bu yüzden işletmeler yeni tüketiciye göre markalarını inşa etmek durumundadırlar. Ryan'ın Jüpiter Araştırma Şirketindeki analistlerden aktardığına göre bu etkileri yedi önemli başlık altında incelemek mümkündür;

Bunlardan birincisi, karşılıklı bağlantı konusudur. Yani sadece firmalar ile tüketiciler arasındaki bağlantı değil, tüketiciler ile tüketiciler arasındaki bağlantı da hayati öneme sahiptir. Elektronik postalar, anlık mesajlaşma uygulamaları, sosyal medya hesapları ve bunların aynı anda hepsinin birden kullanımı bu durumu çarpan etkisi ile büyütmekte ve güçlü kılmaktadır. Tüketiciler sınırlar ve kısıtlamalar olmaksızın, dünyanın dört bir 
tarafındaki diğer tüketiciler ile bilgi alışverişi yapabilmektedirler. Bu da her markanın veya ürünün çevresinde yeni bir dijital topluluğun oluşmasına sebep olmaktadır. Bu durum markalar açısından literatürde pek de yer almayan yeni bir güçlüğü ortaya çıkarmaktadır. Dijital kabilelerin (toplulukların) farklı ülkelerden ve farklı kültürlerden olması sebebiyle işletmelerin globalleşme ile glokalleşme arasındaki dengeyi koruma güçlüğü, işletmeleri bekleyen güçlükler arasında sayılabilir. İkinci bir güçlük, markanın bir ülkedeki yönetici veya personel hatalarının tüm dünyaya sirayet etmesi ve bunun çözümünün çok zor olmasıdır.

Teknoloji kullanımının yaygınlaşmasının tüketici davranışındaki ikinci etkisi, teknolojinin, oyunun kurallarını herkes için eşitlemesidir. Bu durum işletmeler için çok grift bir özellik arz etmektedir. Küçük işletmeler, büyük işletmelerin sahasına girebilir, bir şehirde faaliyet göstermek yerine tüm dünyaya açılarak pazarının coğrafi boyutunu ve pazar payını artırabilir. İçerik yaratabilir, kendisini ve ürünlerini tanıtabilir, diğer markaların ürünleri ile kıyaslanma imkanına kavuşabilir. Tabi ki tersi de durum söz konusudur. Teknoloji sayesinde büyük işletmeler dünyanın her yerine yayılabilir, küçük işletmeler üzerinde, maliyet ve fiyat avantajı ile rekabette ezici bir güç uygulayabilirler.

Üçüncü etki, filtreleme olarak adlandırılmaktadır. Bu kadar çok firmanın ürettiği içerikler ve bilgi bombardımanı karşısında tüketici doğal olarak hem kendini korumaya almak, hem de zamanını verimli kullanmak zorunda hissetmektedir. Beğendiği ya da görmek istediği içerik alternatiflerini kişiselleştirerek ön plana çıkarmak, istemediklerini bloklamak ya da yoksaymak suretiyle verilere ciddi anlamda filtre uygulamaktadır. Bunun için geliştirilmiş yazılımların her geçen gün artması ve giderek gelişmesi de buna dayanak olarak ifade edilebilir.

İstenmeyen mesajlar konusunda sadece yazılımlar değil, artık kanunlar da devreye girmektedir. Bir çok ülkede spam olarak adlandırılan her türlü mesaj devlet güvencesinde ciddi yaptırımlar ile karşılık bulmaktadır. Bu da Godin'in (2001) Permission Marketing kavramının önemini her geçen gün artırmaktadır. Çünkü Permission Marketing, kişiseldir, manalıdır ve beklenir (Godin, 2001:35).

Sütütemiz ve Kurnaz'ın (2012:104) bulguları da hem yukarıda bahsedilen durumu hem de alan yazını desteklemektedir. Buna göre tüketiciler kendilerine bilgi sağlandığını düşünüyor ise firmalara izin vermektedirler. Ayrıca, eğlenceli olduğu ve aşırı derecede rahatsız edilmedikleri müddetçe de firmlardan gelen mesajları almaya devam etmektedirler.

Dördüncü etki, niş bütünleşmesinin artması şeklinde karşımıza çıkmaktadır. Özel zevk hobileri uyumlu olan ve bunları sürekli paylaşan insanların birbirlerini bulmaları neticesinde sanal ortamlarda birliktelikler artmaktadır. Yukarıda bahsedilmiş olan dijital kabileler daha homojen küçük gruplara bölünmekte ve öne çıkan bireysel taleplere yoğunlaşma artmaktadır.

Tüketicilerin davranışları üzerindeki beşinci etki, mikro yayıncılıktır. Binlerce yıl önce insanoğlu yazar konumunda idi. Anlatmak istediklerini, ardına bırakmak istediklerini mağara duvarlarına yazdığı dönemlerden bahsediyoruz. Yazının bulunması ve matbaanın icadı ile birlikte insaoğlu okur konumuna geçti. Bu durumu değiştiren devrimsel nitelikteki gelişme elbette internetin icadı olmuştur. Zira internet ile birlikte insanoğlu tekrar okur - yazar konumuna kavuşmuştur. Artık kişisel bloglar ya da mikro bloglar sayesinde insanlar istediği zaman, istediği şeyleri yazmaya, bunları tasnif etmeye, arşivlemeye, uzmanlık alanları veya hobileri konusunda panolar açmaya başlamışlardır.

Hem blogların çokluğu hem de mikro bloglardaki yazarların çokluğu yine işletmeler için bir zorluk ortaya çıkarmıştır. Bu sefer, firmalar tarafından değil, kullanıcılar tarafindan devasa boyutlarda içeriğin üretilmesi ve frmaların bunları takip etme, analiz etme ve mümkünse cevap verme zorluğu... Bu konuda da bot denilen yazılımlar imdada yetişmiştir. Söz konusu yazılımlar her an interneti anahtar kelimeler bazında tarayarak, nerde ne konuşulduğu konusunda işletmelere yardımcı olmaktadır. Bu sistemlerin günümüzdeki gelişmiş versiyonları artık yapay zeka (AI) ile bütünleşmiş ve sorunları 7/24 çözme konusunda ilerleme kaydetmiştir.

Üretici - Tüketicinin yükselişi, altıncı madde olarak karşımıza çıkmaktadır. Kitle üretiminin ve kitlesel pazarlamanın son demlerine yaklşatığımıza dair ifadedir bu aslında. Çünkü artık tüketiciler, üretime müdahil olmakta, ürün prototipinden başlayarak her aşamada söz sahibi olmaktadırlar. İnteraktif uygulamalar, sanal denemeler, hologram teknolojileri gibi kolaylıklar sayesinde, ürünün deneyimi ürün meydana gelmeden yaşanmaktadır. Bu imkanlar tüketicinin kişiselleştirme arzusu ile birleşince ortaya güçlü bir üretici-tüketici profilinin çıktığını söylemek zor olmayacaktır.

Son maddeyi her zaman ve her yerde şeklinde özetlemek mümkündür. Teknolojinin ilerlemesi ile birlikte iş süreçlerinin kısalması, tüketici ihtiyaçlarının daha hızlı karşılanmasına olanak tanımaktadır. Hayatın her alanındaki tüketim hızının artması, tüketicilerin sabırsızlı̆̆ını da beraberinde getirmektedir. Bir ay mektup 
bekleyen insanlardan bir dakikada cevap bekleyen insanlara dönüşen toplumun, ürünlerin eline ulaşma aşamasında da aynı hızı beklemesi artık normal karşılanmaktadır. Aynı gün kargo, ertesi gün teslim hatta büyük şehirlerde aynı gün teslim imkanları gün geçtikçe artmaktadır. Ryan'ın (2014:21) ifadesiyle, "dijital ekonomide zaman, coğrafi konum, yer ve fiziki depolama kapasitesi gibi unsurlar önemsiz detaylar haline gelmektedir".

\section{DİJITAL YAPI}

Eskiden geleneksel medyadan internete geçildiğinde dijital pazarlama aracı olarak sadece internet siteleri ve bunlara bağlı elektronik posta adresleri anılmaktaydı. Günümüzde teknolojinin ilerlemesi ile birlikte hem dijital pazarlama araçlarının sayısı artmış hem de bu araçlara içerik sağlayıcı programlar, yazılımlar ve teknikler artış göstermiştir.

Dijital pazarlama araçları olarak internet siteleri ve bunların mobil versiyonları, siteler ile bağlı elektronik posta adresleri, sektörel pazaryeri siteleri, forumlar, sosyal medya platformları, bloglar, anlık yazışma / mesajlaşma uygulamaları ve bunların ticari versiyonları ile vloglar sayılabilir (Elektrikinfo, 2020). Aşağıda bu araçların belli başlı birkaç tanesine değinilecektir.

\section{1. İnternet Sitesi}

İşletmenin çalışma alanı ne olursa olsun ilk çıktığı günden bugüne kadar internet sitelerinin önemi artarak devam etmektedir. Tüketicilerin firmaya hızlı ve anlık ulaşma arzusu, kurumsal imaj ve verdiği güvenden dolayı internet siteleri hâlâ işletmeler için hayati öneme sahiptir. Özellikle ülkemizde "tr" uzantısını vermeye yetkili tek merkez olması, bu uzantıyı almak için gerçek kimlik bilgileri ile firmanın vergi levhası gibi evrakların istenmesi sebebiyle firmaların gerçekliği konusunda tüketici emin olmaktadır. İnternet sahteciliği ve kredi kartı dolandırıcılığı haberlerinin her geçen gün artması, tüketicilerin güvenilir firmalara ve onların internet sitelerine yönelmesine sebep olmaktadır.

İnternet siteleri, fiziki mağazanın sanal dünyadaki yansıması, bir anlamda vitrinidir. İnternet sitesinin bu işlevlerinin yanısıra banner reklam, elektronik posta, iletişim ve navigasyon bilgilerini barındırma, tüm ürünleri ve özelliklerini sergileme imkanı gibi çok çeşitli imkanları bulunmaktadır.

İnternet sitelerinin gücünü artırmak yani bulunabilirlik seviyesini yükseltmek için arama motorları optimizasyonu (SEO) gibi araçlardan da maksimum seviyede yararlanılması gerekmektedir. Zira günümüzde pek çok insan, internet sitesinin adını bilse dahi, direkt siteye girmek yerine bir arama motoruna yazmak ve oradan link vasıtasıyla siteye geçmek alışkanlığına sahiptir. Bir internet sitesi, sade, şık, görsel tasarımları zevkli, arayüzleri ve sayfaları kullanıcı dostu, aşırı reklamla boğulmayan özellikler sergilemelidir.

\subsection{Sektörel Pazaryeri Siteleri}

Günümüzde sektörel pazaryerleri küçük ve orta ölçekli işletmeler için birincil derecede önemli yerler haline gelmiştir. Büyük ve güvenilir markalar haricindeki küçük ve orta ölçekli işletmelerin direkt internet sayfalarından alışveriş yapma alışkanlıkları giderek gerilemektedir. Bunun başlıca sebebi güven unsurudur. Sektörel pazaryerlerinin aracı rolü, ödenen ücretin, ancak kargo tüketici tarafından teslim alındıktan ve ürün onaylandıktan sonra alıcı hanesine yansıması gibi özellikler ticaretin bu yeni şeklini güçlü kılmıştır. Ücret ödemesine rağmen malın teslim edilmemesi ya da ayıplı olması gibi sorunlar, ticaretin her döneminde ve her şeklinde kendini göstermiştir. Örneğin, Tuğluca (2016:251) tarafindan incelenen ve Başbakanlık Osmanlı Arşivinde yer alan, Haziran 1698 - Aralık 1698 tarihleri arasında tutulan 29 Numaralı Atik Şikayet Defterinde, sipariş edilen bir işin / ürünün bedelinin alınmasına rağmen yapılmaması ile ilgili örnek şikâyet yer almaktadır. Tabi bunun yanı sıra ürün çeşitliliği, firmalar arasındaki rekabetten kaynaklı uygun fiyat avantajları, kampanyalar, ücretsiz kargo gibi firsatlar da tüketicilerin tercih sebepleri arasında sayılabilir.

Nacar ve Özdemir'in (2021:206) alanyazın taramasında aktardıkları özet bilgilere göre, COVID-19'un hem ticari hem de sosyal hayata olan etkileri sebebiyle zaten artmakta olan ticari faaliyetlerin daha fazlası dijital dünyaya taşınmış ve e-ticaret sitelerinden ve sektörel pazaryerlerinden alışverişler artmıştır. Araştırmacıların Bhatti'den (2020:1450) aktardıklarına göre bu dönemde yapılan alışverişlerin yarıdan fazlasında tüketiciler, fiziksel mağazalardan değil, e-ticaret sitelerinden alışveriş yapmak istemişlerdir. 
Fiziksel mağazalarda işletmelerin temel amacı olması gereken müşteri memnuniyeti kvaramı, dijital dünyada ve tabi ki elektronik alış veriş sitelerinde de geçerlidir. Firmaların sağlıklı bir satış sonrası süreç izleyerek, şikayet yönetim sistemlerini, olası senaryolara göre kurgulamaları gerkmektedir. Çünkü Barlow ve Moller'in ifadesiyle (2009), her şikayet bir armağandır. Bu armağanı iyi değerlendiren işletmeler, ürünlerini ve süreçlerini geliştirerek müşteri memnuniyeti konusunda ciddi bir mesafe katedebilirler.

\subsection{Sosyal Medya}

Sosyal medya araçları gün geçtikçe daha fazla önem kazanmaktadır. Kendisi başlı başına bir reklam ve pazarlama mecrası olmamasına karşın, tüketicilerin neredeyse tamamının en az bir sosyal medya aracı kullanması, söz konusu medyayı ister istemez bir reklam ve pazarlama aracına dönüştürmüştür.

Günümüzde özellikle firmaların sosyal medya kullanımı çok standart, daha doğrusu sıradan bir görünüm arz etmektedir. Büyük ölçekli firmalar sosyal medya hesaplarını büyük bütçelerle ajanslara teslim etmiştir. Bu ajansların heme nher gün yaratıcı içerik üretmesi ve viral etkiyi yakalaması zor olduğu için sık sık firmalar ajans değiştirmektedirler. Bu da firmanın sağlıklı ve belirli bir strateji doğrultusunda sosyal medya kullanımına izin vermemektedir. Orta ve küçük işletmelerde ise durum daha kötüdür. Sosyal medya hesapları, bu konudan anladığı varsayılan birkaç kişiye teslim edilerek takip ve stratejiden yoksun, sadece her gün bir şeyler paylaşmak üzerine kurgulanmıştır.

Hootsuite (2021) raporuna göre, dünyadaki sosyal medya kullanımı aşağıda verilen grafikteki gibidir;

Grafik 4. Sosyal Medya Kullanım Oranları

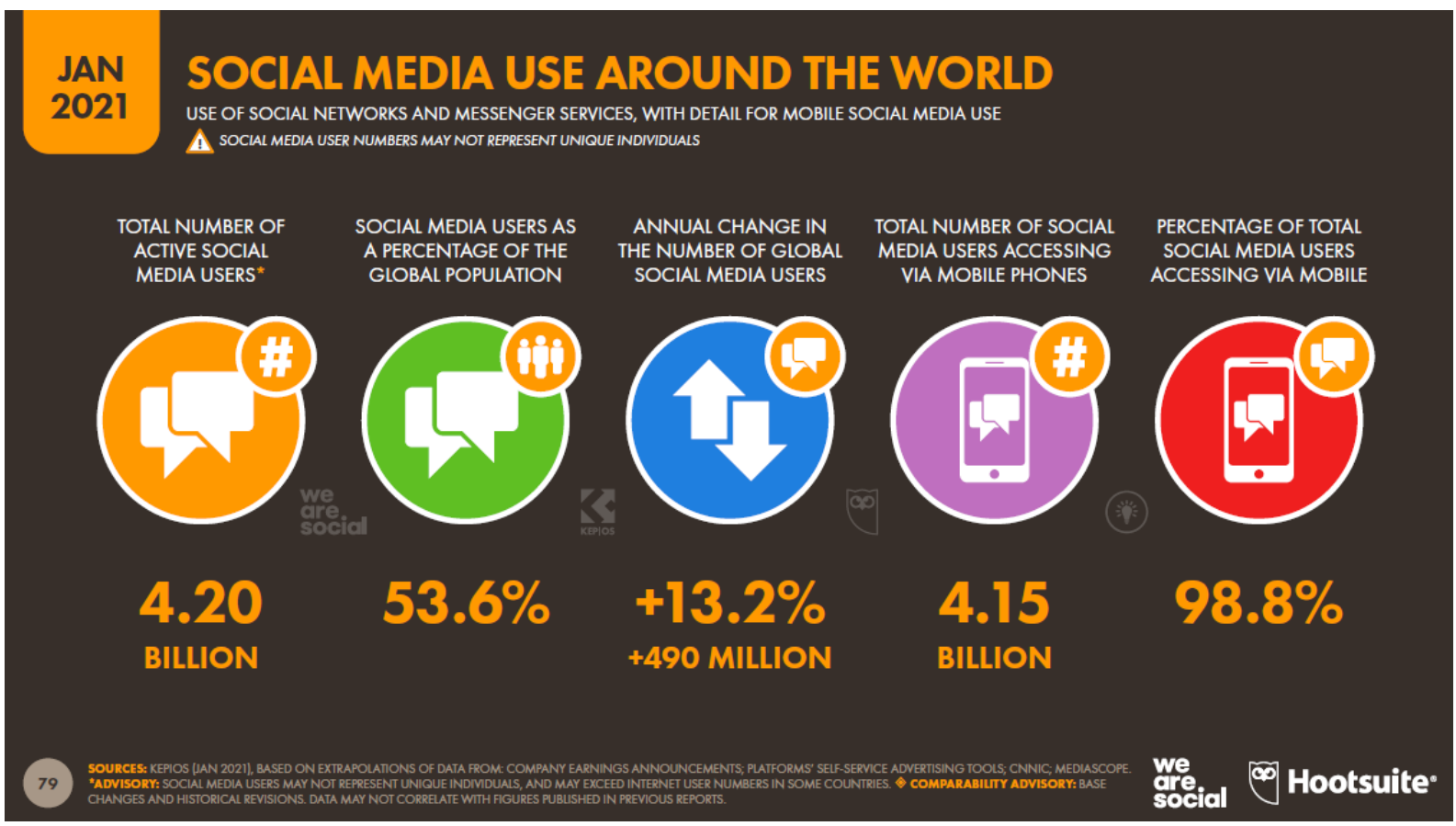

Kaynak: We are Social, Hootsuite, 2021

Peki insanlar tarafından bu kadar yoğun kullanılan sosyal medyada kişiler veya firmalar ne yapacaklardır, nelere dikkat edeceklerdir? Kawasaki ve Fitzpatrick'in (2014) bu konuda detaylı bir madde listesi mevcuttur. Ancak buraya sadece en önemli birkaç ana başlık alınacaktır. Başlıklar aynı zamanda araştırmacı tarafından detaylandırılmıştır. Buna göre;

- Öncelikle profil kısmı kaliteli oluşturulmalıdır. Elbette burada en önemli bölümler isim ve profil fotoğrafı bölümleridir.

- Firmaların akılda kalıcı ve yaratıcı bir motto kullanmaları gerekir.

- Firmanın sıkıcı tarihçesine değil, akılda kalıcı ve dikkat çekici hikayelerine yer vermek daha avantajlı olacaktır.

- Tüm hesaplarda firmanın ismine yönelik URL edinilmesi, kurumsal imaj açısından fayda sağlayacaktır. 
- Bilgi gerektiren tüm alanların dolu olması, firma güvenilirliğini sağlamada etkin rol oynaması muhtemel bir unsurdur.

- Sosyal medyanın hemen her gün içerikle beslenmesi gerekir. (Bu konuya içerik üretimi bölümünde ayrıca değinilecektir).

- Sizin dışınızdaki dünyada neler olup bittiğini sürekli takip etmek ve aynı canlı refleks ile karşıllık vermek, takipçi sayısı konusunda da yardımcı olacaktır.

- Firmaya iletilen mesajların ya da özelden ulaştırılan iletilerin cevapsız kalması, firma açısından olumsuz sonuçlar doğuracaktır.

- Sosyal medya hesaplarının ve firmanın internet sitesinin birbirinden çok ayrı ve kopuk olmamasına dikkat edilmesi gerekmektedir.

\section{6. İÇERIKK YÖNETIMI}

İçerik yönetimi konusuna dijital pazarlama çalışmaları ile ilgili alan yazında pek değinilmemektedir. Ancak içerik, firmaların tüketiciler karşısındaki en büyük imtihanları arasında yer alır. Firmanın tanıtılması, imajı, ürünlerin konumlandırılması, gündemin takip edilmesi, takipçi sayısının artması, onlarla iletişim, viral etkinin yakalanması gibi tüm zaruretler, sağlam bir içerik yönetimi ile başarılabilir.

Scott'un Handley ve Chapman'ın (2013:11) eserine yazdığ önsözde belirtitğine göre pazarlama, mükemmel içerikler sunmaktır. Buradaki en büyük sorun firmaların içerik yaratmakta yetersiz kalmalarıdır. Bugün ister reklamlarda, isterse sosyal medyada üretilen içeriklerde uygulanan yöntem pazarlama değil, propagandadır. Handley ve Chapman (2013:18) doğru türden bir içerik için belli başlı şartların olmazsa olmaz olduğunu belirtmektedirler. Buna göre içerik;

- Müşteri odakl1,

- Sahici,

- İkna edici,

- Eğlenceli,

- Şaşırtıcı,

- Değerli,

- İlginç olmalı. Başka bir deyişle insanların ilgisini çekmelidir.

Yazarlara göre bu şartlar sağlandığında başarılı bir içerik üretimi aslında üç amaç etrafında şekillenmektedir;

1. Potansiyel müşterilere hitap etmek,

2. Onlara değer verdikleri bir şeyler sunmak,

3. Daha fazlası için geri gelmelerini sağlamak.

Ancak bu amaçlara ulaşmak için bazı engellerin aşılması gerekmektedir. Binden fazla işletme üzerinde yapılan bir araştırma, "ilgi çekici içerik" üretmenin, içerik pazarlaması programlarının en büyük zorluğu olduğunu bulmuştur (Handley ve Chapman, 2013:19). Söz konusu ankete dair verilerin tasnif edildiği grafik aşağıdaki gibidir; 
Grafik 5. İçerik Pazarlamasının En Büyük Sorunları

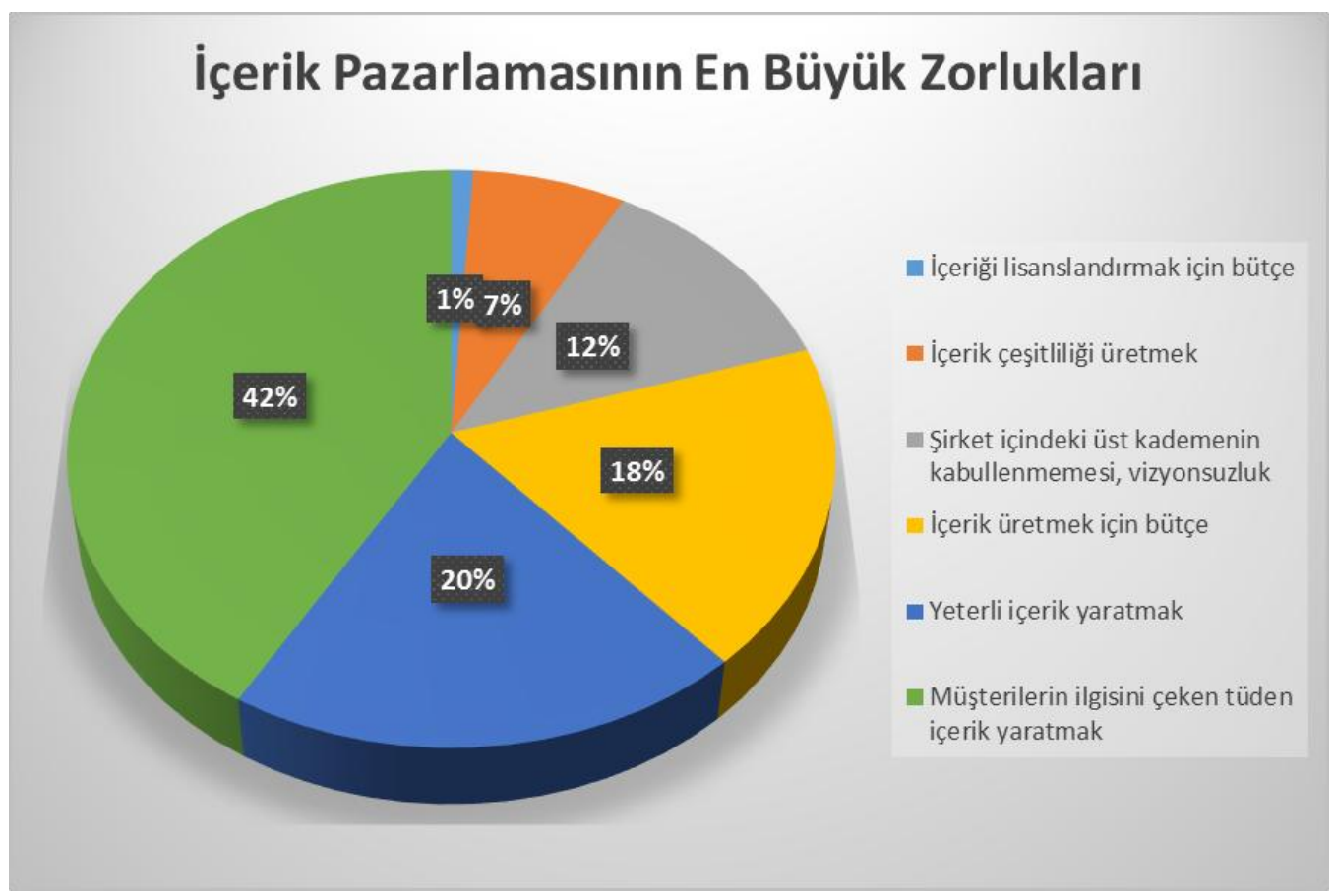

Kaynak: Handley ve Chapman, 2013.

İçerik üreticilerinin karşı karşıya bulunduğu sorunların başında planlama gelmektedir. Sosyal medya sürekli içerik bekleyen bir mecra olduğu için paylaşılacak içeriklerin iyi planlanması, özel gün ve haftalar dikkate alarak takvimlendirilmesi gerekmektedir. Bunlardan başka ayrıca sosyal medyada, ülke ve dünya gündeminin sürekli takip edilmesi, kullanıcıların refleks gösterdiği konular ile ilgili paylaşımların tasarlanması işletmeler açısından faydalı olacaktır. Ancak bu planlamaların da hedefine ulaşabilmesi için cevaplanması gereken sorular vardır. Hedef tüketicimiz kim, nelerde hoşlanıyorlar, beklentileri neler, nasıl tepki veriyorlar, hangi konular ilgilerini çekiyor, ne tür mesajlar verilecek gibi.

İkinci sorun, bu plan dahilinde yapılacak (veya plan haricindeki paylaşımlar - kaza, toplu ölüm, afet vb.) paylaşımlara ait metinlerin kaleme alınmasıdır. Eğer içerik üretimi için yeterli bütçe ayrılmadıysa veya firma içinden birileri sadece yapmış olmak için bu işi yapıyorsa yaşanacak aksaklıklar kaçınılmazdır. Profesyonel olmayan metinler ya firma politikaları ile uyuşmayacak ya da başka sayfalardan kopyala - yapıştır tekniği ile alındığı için belli bir süre sonra sosyal medyada alay konusu olacaktır. Bu da tüketicilerin firma hakkındaki düşüncelerini ve firmaya bakışını ciddi derecede etkileyecektir.

Dijital pazarlamada bir içeriğin metinsel özellikleri nasıl olmalıdır sorusuna veerilecek cevaplar onlarca olabilir. Ancak temel bazı şartların yerine getirilmesi, içeriğin kalitesi açısından önemlidir. $\mathrm{Bu}$ şartları sıralayacak olursak;

- Metnin özgün olması,

- Anlatım bozukluğu vb hataların olmaması,

- Punto ve yazı karakteri açısından okunabilir olması,

- Metnin yani içeriğin anlamlı bir şey söylemesi, bir şey ifade etmesi, kısacası işletme lehine olumlu etki yaratacak güçte olması,

- Metnin / mesajın tam ve açık yani anlaşılır olması,

- Başka anlamlara gelecek imalar, göndermeler içermemesi,

- Tasarım veya videolarda rahatsız edici derecede aşırı renk ve hareket olmaması,

- Bilgi içeriyorsa, bu bilgilerin doğru olması gerekmetedir. 
Metinlerin de hazırlanmasının ardından firmaları bekleyen üçüncü sorun, tasarım aşamasıdır. Tasarım ilüstrasyon, resim, grafik vb şekillerde olabilir. Buna karar verilmesinin yanısıra bu tasarımı yapabilecek donanıma sahip grafiker, çizer ve tasarımcı ekibinin varlığı başlı başına en büyük meselelrden birisidir. Bu ekibin, yeterli düzeyde teknik bilgiye sahip olması ile birlikte, kurumsal renklere, tasarımlara, kurum felsefesine, marka ruhuna kısacası işletme ve marka ile ilgili maddi ve manevi tüm unsurlara hakim olması gerekmektedir. Eğer paylaşım video olacak ise iş daha karmaşık hale gelmektedir. Video sosyal medyada grafiklere ve tek boyutlu tasarımlara göre daha fazla ilgi çekmektedir. Ancak video başı başına ciddi bir prodüksiyon anlamına gelmektedir. Elbette ciddi bir viral etki sağlam içerikli bir video ile yakalanabilir. Böyle bir videonun meydana getirilmesi ciddi bir planlama, bütçe, zaman, ekip ve emek gerektirmektedir.

Tüm bu adımlardan sonra en önemli konu zamanlama konusudur. Paylaşımların ne zaman, hangi saat dilimlerinde yapılacağı başlı başına bir çaba gerektirir. Günümüzde bu konuya yardımcı olacak çeşitli istatistikler sürekli yayınlanmaktadır. Ayrıca işletmenin kendi sosyal medya hesaplarının sunduğu istatistiki bilgiler de bu konuda yardımcı olacaktır. Ayrıca paylaşımları önceden yükleyip istediğiniz zaman kendi kendi paylaşan yazılımlar da mevcuttur. Büyük işletmelerin bir çoğu bu tür programlar kullanmaktadır. Ancak göz ardı edilmemesi gereken bir durum vardır. Şöyle ki sosyal medyada hayatın 24 esasına göre devam ettiği gerçeği. Yani firmanın, insanların en yoğun sosyal medya kullandığı saate neşeli bir paylaşım planlayıp programa yüklediğini varsayalım. $\mathrm{O}$ dakikalarda bir afet, bir şehit haberi veya dünyada önemli bir gelişme haberlere ve sosyal medyaya düsserse, firma da programa güvenip sosyal medyayı takip etmiyor ise, firma imaj1 açısından ciddi sonuçlarla karşı karşıya kalacaktır.

Son olarak dijital pazarlamanın reklam kısmına değinmek gerekmektedir. Elbette geleneksel medyaya göre, internet reklamları veya sosyal medya çok daha ekonomik bir bütçe ile çalışmaktadır. Ancak yine de bu reklamların firma politikaları ve amaçları ile uyumlu bir şekilde koordine edilerek hayata geçirilmesi gerekmektedir.

\section{MARKALARIN MÜŞTERİ MEMNUNIYETI}

Markaların ya da daha doğrusu işletmelerin, kendilerini müşteriye anlatmasında, ikna etmesinde ve bağ kurmasında en önemli adım kendisinin farkına varmasıdır. Marka nedir dendiğinde sosyal bilimler alanında bir çok tanıma rastlamak mümkün olsa da Aaker'in (2014:9) de belirttiği gibi marka, isim ve ona uygun logonun ötesinde aslında bir söz, bir vaattir. Aaker (2014:12) markalaşma konusunda izlenecek adımları şu şekilde sıralamıştır;

- Markaların stratejik değeri olan varlıklar olarak kabul edilmesi,

- Marka vizyonuna sahip olma,

- Söz konusu marka vizyonunu hayata geçirme,

- Marka uygunluğunu sürdürme,

- Marka portföyünü yönetme ve avantajlı hale getirme.

Markaların bu şekilde varlık olarak hayata bulması sonucunda müşteri nazarında bir değer atfedilmesi ya da bununla ilgili çalışmaların yürütülmesi daha da kolay olacaktır. Bu süreç başarılı işletilir ise markanın, müşteri memnuniyetini etkileyecek çeşitli boyutlarının ve anlamlarının karşılığı alınabilir. Çünkü artık burada markalar ile ilgili konularda duygular ön plana çikacaktır.

Bu duygular Marka Küllliyatı (Altunışık vd., 2020) adlı çalışmada da değinildiği sıra ile anlatacak olursak, markaya duyulan güven ile başlayabilir, güvenin artması sadakata dönüşebilir, sonrasında bir marka aşkından bahsedilebilir. Öncelikle, markanın, müşteri için ifade ettiği veya müşteriye vaadettiği değeri karşılaması öncelikli şarttır. Zira Arslan ve Altunışık'ın (2020) da ifade ettiği gibi, günümüz iş dünyasında markalar, ürünlerin bir unsuru olmaktan çıkmış, ürünün kendisi markayı oluşturan bir unsur haline gelmeye başlamıştır.

$\mathrm{Bu}$ değeri karş1layan markalar, müşteri tarafinda bir güven inşa etmeye başlayacaklardır. Çünkü, "günümüz tüketicisinin değişim ilişkisi kurduğu marka / kurumdan temel beklentisi ilişkinin güven temelli olmasıdır" (Çıldır, 2020: 107). Burada en çok göz ardı edilen nokta, tüm bu kavramların tüketiciyi satın almaya götüreceği düşüncesidir. Her ne kadar internetin yaygınlaşması öncesi yapılan araştırmalarda bu yönde bulgular olsa da günümüz internet dünyasında bu durum her zaman böyle gerçekleşmeyebilir. Yani markaya güvenen kişi satın almada ilk sırada tercih etmeyebilir. İnternet üzerinden etkilendiği, kararını vermede etken olan başka 
değişkenler sebebiyle markaya olan güven arka sıralarda kalabilir. Dijital ortamlardaki topluluk görüşlerinden tutun da, influencerlerin görüşleri marka güveni değişkenini olumsuz yönde etkileyebilir.

Marka sadakati konusu da alan yazında giderek tartışılan konular arasına girmiştir. En çok dile getirilen söylem, markalara gerçekten de söylendiği kadar sadakatin kalıp kalmadığıdır. Örneğin Walker (2010:XIII) New Yorker dergisini referans göstererek tüketicilere ulaşan bilgilerde yaşanan patlama sebebiyle marka sadakatinin hızlı bir düşüş içinde olduğunu ifade eder.

Hemen hepimiz günde hatırı sayılacak bir süreyi internette geçiriyoruz. Alması en kolay, ulaşması en kolay, fiyatı en uygun, ücretsiz kargo gibi onlarca değişken bizi etkilerken sadakat hissimiz olan markayı tercih etme olasılığının düştügü artık aşikar.

Güven ve sadakat konuları karşısında görece daha avantajlı olan kavram muhtemelen marka aşkıdır. Marka aşkı oluşturabilmiş markaların, satın alma sürecinde tercih edilme ihtimalleri daha yüksektir. Bu kavramların önemindeki değişme şüphesiz teknolojidir. Teknolojinin gelişmesi ile birlikte büyüyen dijital dünya, firmalar açısından her zaman bir avantaj olarak görülmektedir. Ancak tersi durum da söz konusu olabilir. Bu durumu Yılmaz (2020), "Tüketicilere ulaşma kanalları bakımından alternatiflerin çoğalması işletmeler açısından kolaylık olduğu kadar zorluklara da neden olmaktadır. Artık oluşturulan bir mesajın ki bu en iyi tasarlanmış bir mesaj olsa bile hedef kitleye iletilmesinde hem çok fazla sayıda araca başvurulması hem de bu araçlar arasında anlamlı bir bütünlüğün sağlanabilmesi için doğru bir zaman planlamasına ihtiyaç bulunmaktadır" şeklinde ifade etmiştir.

İnternet ve sosyal medya görece yeni ve bildiğimiz klasik dünyaya göre çok farklı gibi görünebilir. Ancak dijital dünyanın büyük bir bölümünde halen geleneksel pazarlamada kullanılan tekniklerin işe yaradığını da göz ardı etmemek gerekmektedir. Bunun en önemli sebebi elbette insan doğasının ve psikolojisinin ana ilkeleridir. Bu konuda yapılan bir araştırmada Rennie ve Davies (2021) arama ağı reklamlarının etkisini nasıl artıracaklarını araştırırken bir yandan da davranış biliminin beş ilkesinden yararlanmışlardır. $\mathrm{Bu}$ ilkeler aynı zamanda geleneksel pazarlama tekniklerinde de kullanılan bilindik ilkelerdir ve internette de sonuç vermiştir. Kullanılan beş ilke şöyle açılanmaktadır;

- Illk olarak Bedavanın Gücü: Alışverişle birlikte ücretsiz ürün, teklif ve kuponlar sunulması, tüketici için büyük bir motivasyon kaynağı olabilir. Anderson (2011) da "Bedava" adlı kitabında bu konuyu geniş bir çerçevede, güncel hayattan örneklerle ele almıștır. Buna göre "bedava"nın ciddi bir paradoksu vardır ve sıfır para birimi etrafında, orta ölçekte bir ülke ekonomisi büyüklüğünde bir ekosistem yaratılmıştır. Gerçekten de dijital dünyanın en büyük getirilerinden birisi, maliyetlerin en alt seviyelerde seyrediyor olmasıdır. $\mathrm{Bu}$ da dijital pazarlama bütçesinin daha fazla pay alabilecği anlamına gelir. Bu firsatı yakalayan firmaların, tüketicilere sunduğu bedava hizmetler, kendilerine çok ciddi miktarlarda paralar olarak dönmektedir.

- Rennie ve Davies'in (2021) kullandığı ikinci temel davranış bilimi ilkesi otorite ön yargısıdır. Buna göre, markalar, ürünler ve hizmetler, uzmanlar ile güvenilir kaynaklar tarafindan desteklendiğinde rakiplerine kıyasla bir adım öne çıkar.

- Üçüncü ilke çerçeveleme ilkesidir. Yani, referans çerçevesini değiştirmek, kullanıcıların ürünün veya hizmetin değerini yeniden gözden geçirmesini sağlayabilir. Çerçevelemeden yararlanarak örneğin kullanışlılık ve zaman tasarrufu gibi avantajları vurgulayabilirsiniz.

- Dördüncü ilke toplumsal kanıt ilkesidir. Başka insanların, uzmanların veya herhangi bir konuda kanaat önderi diye nitelendirilebilecek insanların önerileri, tüketiciler tarafinda her zaman değer bulmuştur. Rennie ve Davies de aynı noktaya vurgu yaparak, "Yorum ve önerilerden yararlanmak veya ürünün ya da hizmetin alakalı bir referans grubu arasında popüler bir seçim olduğunu vurgulamak, çok ikna edici yöntemler olabilir", demektedir. Bu durumun diğer bir yönü de alınan mal ya da hizmetin bir referans grubu tarafindan onaylanıp onaylanmamasının, firma açısından risk boyutunda yarattığı değişimdir. Yıldız'a göre (2017) tüketicilerin satın aldıkları ürünlerin çevresi tarafından onaylanmaması firma açısından risk değeri taşımaktadır.

- Son ilke, maliyetli sinyalizasyon ilkesidir. Burada "premium ilişkilendirmeler yaparak (ör. Super Bowl'da reklam yayınlamak) ürünün premium olduğunu gösterebilirsiniz" diyerek araştırmacılar, aslında tanınmış olmanın tüketicide yaratacağı güven duygusuna da atıfta bulunmuşlardır. 


\section{GENEL DEĞERLENDIRME}

Teknoloji, kapsamı ne olursa olsun her zaman yeni pazarlar ortaya çıkarmada mahir olmuştur. Hem mevcut pazarları değiştirme, hem de yeni iş ve istihdam alanları yaratmadaki etkisi sebebiyle, teknolojiyi pazarlamadan ayrı görmek neredeyse imkansızdır.

Çalı̧̧maya bahis teknoloji ise özünde ağ teknolojileri olarak genelleştirilen, bizim internet diye bildiğimiz teknolojidir. Bu teknolojinin çıktıları ve getirileri olarak sayılan web, mesaj sistemleri ve programları, sosyal medya, elektronik posta vb unsurların tamamı bugün pazarlama disiplini ile bir bütün olarak değerlendirilmektedir.

Dijital pazarlama, bugune kadar getirdiği pazarlama ilkelerinin teknoloji ile buluşmuş hali demek yetersiz bir ifade olabilir. Zira yukarıda anılan teknolojiler tüketiciyi değiştirmiştir. Pazarlama disiplini hem değişen tüketiciye uygun olarak pazarlama tekniklerini güncellemek hem de yeni teknolojilere adapte olmak durumundadir.

Dijital dünyanın ilk dönemlerindeki kabüllerin ve argümanların da değiştiğinin görülmesi gerekmektedir. Mesela, intenetin çıkışıyla beraber firmanın sadece coğrafi hinterlandındaki değil, internetteki herkes tarafından kolayca bulunabileceği ifade edilmekteydi. Bu durum o zamanlar için doğru olmakla birlikte bugün durum farklılaşmıştır. Firmaların, tüketici tarafından bulunması yönünde iki zorlu engel vardır. Bunlardan birincisi arama motorlarının sayısının azlığı hatta bir tanesinin ezici galibiyetidir. Bütün bir dünya hadi daha iyimser bir söylemle koca bir ülkenin firmaları arasından arama motorunda ilk sayfada çıkma ihtimali, bir firma için çok azdır. İkinci engel ise internette rekabetin aşırı derecede fazla olması, nette yer almanın kolaylığından ötürü resmi kurulmuş olsun olmasın işletmelerin ya da ürünlerin rahatça dijital mecralarda bulunmasıdır. $\mathrm{Bu}$ da işletmenin rakipleri arasından sıyrılıp tüketiciye ulaşmasını zorlaştırmaktadır.

Elbette arama motorlarında bulunabilmek için SEO adı verilen optimizasyon çalışmaları mevcuttur. Fakat bu çalışmalar neredeyse tüm kullanıcılar ya da ajanslar tarafından uygulanmaktadır. Yani değişen pek bir şey olması ihtimali zordur.

Arama motorlarında SEO ayarları ile yükselme ihtimalinin olmadığı ya da çok az olduğu durumlarda görünür olabilmek için reklam verme seçeneği düşünülebilir. Ancak bu da çok dar zamanlı, kalıcı olmayan ve diğer sosyal medya araçlarına nazaran görece pahalı bir yöntemdir.

Arama motorlarında tüketiciye ulaşma şansının az olduğu durumlarda firmaların en önemli tercihlerini sosyal medya hesapları oluşturmaktadır. Ancak bu mecraları da etkili ve verimli kullanabilmek için ciddi bir bilgi birikimi ve çaba gerekmektedir. Söz konusu alanda yapılması gerekenler çalışmaın ilgili bölümünde yer almıştı.

Sosyal medya hesaplarının aşağı yukarı işlevselleştiği dönemlerde ek olarak elektronik posta ile tüketiciye daha özel ve birebir ulaşma ihtimali düşünülebilir. İnternetin ilk çıktığı dönemlerde ve soyal medyanın henüz olgunlaşmadığı zamanlarda elektronik posta ile pazarlama aktif olarak kullanılan bir yöntemdi. Günümüzde tekrar önemsenmesinin sebebi, tüketicinin dikkatini çekebilmek, ona özgü ve kişiselleştirilmiş reklamları ulaştırabilmek gayesidir. Fakat elektronik posta pazarlamasının da riskleri mevcuttur. Bu risklerin başında istenmeyen posta yani spam gelmektedir. İstenmeyen postalar konusunda fikir verebilecek izinli pazarlama konusu çalışmada ele alınmıştır.

Dijital pazarlamanın günümüzde en önemli ayaklarından birisi de sosyal medya mecralarıdır. Bu yüzden sosyal medyay1 iyi anlamak, her bir alanın kendine has dinamiklerini bilmek ve ona uygun davranmak gereklidir. Bugün bir çok firma Twitter'i Facebook gibi, Facebook'u Instagram gibi kullanma hatasına düşmektedir. Hangi mesaj, hangi sosyal medya mecrasında, kime ve nasıl ulaşır sorularının firmalar tarafından yeterince sorulmadığ1 görülmektedir. Bu mecralar için hayati öneme sahip içerik yönetimine dair gereklilikler ve dikkat edilmesi gereken konulara da çalışmada yer verilmiştir.

İlerleyen çalışmalarda dijital pazarlamanın sadece bu kısmı ile ilgili ayrıntılı incelemeler yapılabilir. Dijital pazarlama faaliyeletlerinin ölçümlenmesi, reklamların verimliliği, kullanılan bütçenin dönüş oranlarının hesaplanması, dijital pazarlama ve dijital halkla ilişkilerin iç içe geçtiği konular, izinli pazarlama ve mahremiyet gibi araçtırmacıları bekleyen bir çok konu vardır. 


\section{KAYNAKÇA}

AAKER, David (2014), Markalama, MediaCat Yayınları, İstanbul.

AKSOY, Temel (2020), "Dijital Müşteri Davranışları", E-Makale, www.temelaksoy.com, https://www.temelaksoy.com/dijital-musteri-davranislari/ (Erişim Tarihi: 03.10.2021).

ALTUNIŞIK, Remzi, ZENGIN, Burhanettin ve YILDIRIM, Yıldırım (2020), Marka Külliyatı, Nobel Yayınları, Ankara.

ANDERSON, Chris (2011), Bedava (Çev. G. Aksoy), Optimist Yayınları, İstanbul.

ARSLAN, Yusuf ve ALTUNIŞIK, Remzi (2020), "Marka Değeri", Marka Külliyatı (Ed. R. Altunışık, B. Zengin, Y. Yıldırım), Nobel Yayıncılık, Ankara, ss.3-18.

ARTHUR, Brain (2011), Teknolojinin Doğası (Çev. İ. Çetin), Optimist Yayınları, İstanbul.

BARLOW, Janelle ve MOLLER, Claus (2009), Her Şikayet Bir Armağandır (Çev. G. Bilgili), Rota Yayınları, İstanbul.

CHAFFEY, Dave ve SMITH, Paul Russell (2013), Emarketing Excellence, Planning and Optimizing Your Digital Marketing, Routledge Publisher, Abingdon.

ÇILDIR, Çetin (2020), "Marka Güveni", Marka Külliyatı (Ed. R. Altunışık, B. Zengin, Y. Yıldırım), Nobel Yayıncilık, Ankara, ss.107-125.

DEMIR, Didem ve YILDIZ, Selçuk Yasin (2021), "The Mediating Role of Consumer Engagement in the Effect of Social Media Marketing on Electronic Word-of-mouth Intention", Business \& Management Studies: An International Journal, S.2(9), ss.649-661.

ELEKTRIKİNFO (2020), "Geleneksel Pazarlama ve Dijital Pazarlama Araçları Nelerdir?", Elektrikinfo Kurumsal Web Sayfası (E-Makale), https://elektrikinfo.com/geleneksel-pazarlama-ve-dijitalpazarlama-araclari-nelerdir/ (Erişim Tarihi: 03.08.2021).

GODIN, Seth (2001), Permission Marketing (Çev. M. Ermert), Rota Yayıncılık, İstanbul.

HANDLEY, Ann ve CHAPMAN, C. C. (2013), Dijital Çağda İçerik Yönetiminin Kuralları (Çev. Z. Kökkaya), MediaCat Kitapları, İstanbul, 2. Baskı.

HOOTSUITE (2021), "Dijital 2021", Wearesocial Kurumsal Web Sayfası (E-Makale), https://wearesocial.com/digital-2021 (Erişim Tarihi: 03.08.2021).

KAWASAKI, Guy ve FITZPATRICK, Peg (2014), Sosyal Medya Sanatı (Çev. M. Benveniste), MediaCat Kitapları, İstanbul.

KOÇAK ALAN, Alev, TÜMER KABADAYI, Ebru ve ERİ̧̧KE, Tuğbay (2018), "İletişimin Yeni Yüzü: Dijital Pazarlama ve Sosyal Medya Pazarlaması", Elektronik Sosyal Bilimler Dergisi, S.17(66), ss.493-504.

NACAR, Ramazan ve ÖZDEMIR, Kadir (2021), "E-Ticaret Pazaryeri Web Sitelerinin Dinamikleri: Covid-19 Pandemi Sürecindeki Değişim", Eskişehir Osmangazi Üniversitesi İktisadi ve İdari Bilimler Fakültesi Dergisi, S.16(1), ss.205-226.

RENNIE, Alistair ve DAVIES, Sian (2021), "Arama A ̈̆g Reklamlarının Etkisini Artırma Davranış Eğilimleri", Think with Google (E-Makale), https://www.thinkwithgoogle.com/intl/tr-tr/pazarlamastratejileri/arama/arama-agi-reklamlarinin-etkisini-artirma-davranisegilimleri/?utm_medium=email\&utm_source=d-content-alert\&utm_team=twg-tr\&utm_campaign=twg-trcaa\&utm_content=cta-btn\&mkt_tok=MTcyLUdPU (Erişim Tarihi: 03.08.2021).

RYAN, Damian (2014), Dijital Pazarlama (Çev. M. M. Kemaloğlu), İş Bankası Yayınları, İstanbul.

SCHMIDT, Erich ve COHEN, Jared (2014), Yeni Dijital Çăg (Çev. Ü. Şensoy), Optimist Yayınları, İstanbul.

SÜTÜTEMIZ, Nihal ve KURNAZ, Aysel (2012), "Mobil Pazarlama Kapsaminda İzinli Uygulamalar Etkileyen Boyutların Belirlenmesi: Sakarya Üniversitesi Öğrencileri Üzerine Bir Uygulama", Sakarya İktisat Dergisi, S.1(4), ss.82-108. 
TUĞLUCA, Murat (2016), Osmanlı Devlet - Toplum İlişkisinde Şikayet Mekanizması ve İşleyiş Biçimi, Türk Tarih Kurumu Yayınları, Ankara.

WALKER, Rob (2010), Değişen Tüketici Kim? (Çev. N. Özata), MediaCat Yayınları, İstanbul.

YILDIZ, Selçuk Yasin (2017), "Internet Üzerinden Alışveriş Yapan Bireylerde Risk Algısı ile Memnuniyet ve Memnuniyetsizlik Etkileşimi", Pazarlama İçgörüsü Üzerine Çalışmalar, S.1(1-2), ss.32-40.

YILMAZ, Aykut (2020), "Dijital Dönüşümde E-Ticaret ve Pazarlama Uygulamalart", Endüstri 4.0'dan Toplum 5.0'a Güncel Yaklaşımlar (ED. S. Çiğdem, A. Boztaş), Nobel Yayıncılık, Ankara, ss.297-308.

YOLCU, Tarık ve ARSLAN, Yusuf (2020), "Pazarlama 4.0 ve Perakendecilik Sektöründeki Yansımaları", Endüstri 4.0'dan Toplum 5.0'a Güncel Yaklaşımlar (ED. S. Çiğdem, A. Boztaş), Nobel Yayıncılık, Ankara, ss.255-264.

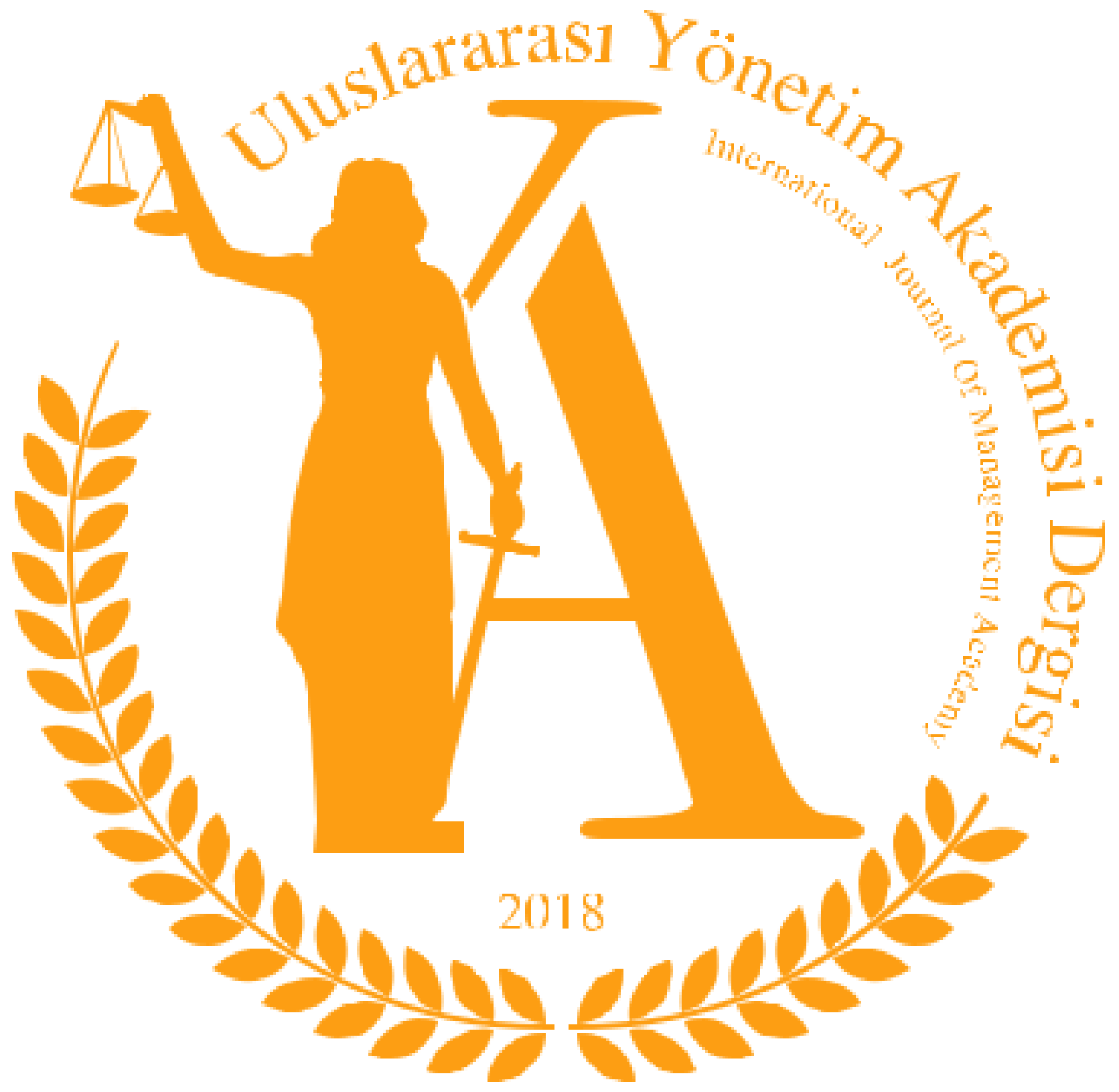

